\title{
Zinc and copper concentrations in leucocytes and erythrocytes in healthy adults and the effect of oral contraceptives
}

\author{
LESLEY J HINKS, BARBARA E CLAYTON, RS LLOYD \\ From the Department of Chemical Pathology and Human Metabolism and the Professorial Medical Unit, \\ Medical Faculty of the University of Southampton, Southampton General Hospital, Southampton
}

SUMMARY The content of zinc and copper of whole blood, plasma, erythrocytes and white cells, 6 has been measured in normal controls. The concentrations of zinc and copper in leucocytes are $\vec{\circ}$ about seven and ten times respectively higher than those in erythrocytes. Women taking oral $\vec{\sigma}$ contraceptives showed significant increases in the concentrations of copper in plasma and whole $\frac{\text { 의 }}{3}$ blood but not in leucocytes or erythrocytes. Oral contraceptives did not alter the concentration of $\vec{c}$ zinc in any of the fractions or in whole blood. These data provide a baseline for the assessment of $\mathbb{D}$ the body status of zinc and copper in various disease states in which deficiencies may be present.

Zinc and copper are two of the most intensively investigated essential trace elements but none of the methods currently used to assess their body status is ideal. ${ }^{1}$ Attempts to determine body zinc and copper status from the concentrations of zinc and copper in biological tissues and fluids such as plasma, serum, whole blood, urine, hair, saliva, fingernail, and skin have been shown to be generally inadequate for diagnostic purposes. ${ }^{2}$ Elemental concentrations in plasma or serum are the most widely used indices of copper and zinc nutrition, but their circulating concentrations may be increased or decreased by many factors. Oestrogens, corticosteroids, and stress situations including infections, influence the production or release of caeruloplasmin which contains more than $90 \%$ of the copper circulating in plasma. The total circulating concentrations of zinc in serum are dependent on both serum albumin concentration and the affinity of albumin for zinc. Approximately $80 \%$ of the circulating zinc is bound loosely to albumin and approximately $20 \%$ is tightly bound to alpha-2-macroglobulin. ${ }^{3}$ Erythrocytes and leucocytes are components of haemopoietic tissue which are readily accessible for biochemical analysis. Measurements of copper and zinc in erythrocytes may be useful for indicating long-term zinc and copper status since these cells have an average life-span of 110 days. ${ }^{4}$ The analysis of leucocytes may reflect more accurately acute changes in zinc and copper

Accepted for publication 20 April 1983 status as these are metabolically more active and $\stackrel{\mathbb{\Phi}}{-}$ have a shorter life span than erythrocytes, arof $\varphi^{\circ}$ because they (unlike erythrocytes) are nucleated, the $\omega$ are more likely to be representative of other cells. Фt has been demonstrated that leucocyte zinc can be lowered by experimental zinc deficiency in $\operatorname{man}^{5}$ and reduced leucocyte zinc concentrations have been reported in patients with liver disease, indicating $a \stackrel{\circ}{\stackrel{\Phi}{\varrho}}$ possible tissue zinc deficiency. ${ }^{6}$

The present study was undertaken to investigate $\frac{0}{3}$ the concentrations of zinc and copper in whole? blood, plasma, erythrocytes and leucocytes of nor-क mal human subjects, in order to provide control data for use in studies of metabolic disorders that may? involve copper and zinc.

\section{Patients, material and methods}

SUBJECTS

Whole blood was obtained from 119 normal healthy 응 volunteers: 55 men aged 18-63 yr and 64 women aged 21-57 yr. Of the women who participated, 22 . were regularly taking combination type (ethinyloes- $N$ tradiol $30 \mu \mathrm{g}$, levonorgestrel $150 \mu \mathrm{g}$ ) oral contraceptives ("the pill").

\section{SAMPLES}

Samples $(19 \mathrm{ml})$ of venous blood were collected be-co tween 0900 and $1100 \mathrm{~h}$ and the sample was sub-市 divided in the following way:

$15 \mathrm{ml}$ was transferred to a siliconised glass tube for $\square$ leucocyte separation; 
$2 \mathrm{ml}$ was added to a trace-metal-free tube containing heparin for erythrocyte and plasma separation; the remaining $2 \mathrm{ml}$ was added to a trace-metal-free tube containing EDTA for the determination of full blood count, packed cell volume and whole blood copper and zinc determination.

\section{Leucocyte separation and analysis}

Leucocytes were separated and analysed for copper and zinc content as previously described. ${ }^{7}$

\section{Plasma analysis}

Plasma was analysed for copper and zinc by a modified version of the method of Meret and Henkin. ${ }^{8}$

Within and between-batch precisions were: $2.4 \%$ and $3.1 \%$ for zinc at $15.5 \mu \mathrm{mol} / \mathrm{l}$; and $2.8 \%$ and $3.9 \%$ for copper at $17.5 \mu \mathrm{mol} / \mathrm{l}$.

\section{Erythrocyte separation}

The red blood cells obtained from the heparinised blood samples were washed three times with $0.9 \%$ saline. After the last wash, a volume of saline approximately equal to the volume of red blood cells was added.

\section{Cell counting}

Red blood cell counts were determined on the whole blood and red cell suspensions using a Coulter Counter, Model DN, in conjunction with the Coulter Dual Dilutor III.

\section{Haematocrit measurement}

Haematocrit measurements were made with a microhaematocrit centrifuge (Hawksley), spinning at $13000 \mathrm{~g}$ for $5 \mathrm{~min}$.

\section{ANALYSIS OF COPPER AND ZINC IN WHOLE}

BLOOD AND ERYTHROCYTES

Before copper and zinc analysis the samples were frozen at $-20^{\circ} \mathrm{C}$. Thawing produced complete haemolysis of the red blood cells and homogeneous samples were obtained after dilution.

\section{Reagents}

All reagents were obtained from BDH Chemicals Ltd, Poole, Dorset.

Zinc chloride standard solution, $5 \mathrm{mmol} / \mathrm{l}$ of zinc. Copper (II) chloride standard solution, $5 \mathrm{mmol} / \mathrm{l}$ of copper.

Triton X-100, $0.01 \% \mathrm{vol} / \mathrm{vol}$ aqueous solution. Butan-1-ol, "Aristar" grade $6 \% \mathrm{vol} / \mathrm{vol}$ aqueous solution.

Water, deionised distilled water was used throughout.

\section{Instrumentation}

A Perkin-Elmer 560 atomic absorption spectrophotometer was used for the measurement of copper and zinc by atomic absorption spectrophotometry using an air-acetylene flame.

\section{Glassware}

All glassware was first cleaned with $5 \%$ vol/vol Decon 75 solution, then soaked in $10 \% \mathrm{vol} / \mathrm{vol}$ nitric acid for approximately $12 \mathrm{~h}$, followed by six rinses with deionised distilled water.

\section{Stock blood sample}

A stock sample of whole blood was obtained by venepuncture from a healthy adult and the blood was transferred to and stored at $-20^{\circ} \mathrm{C}$ in a series of $2 \mathrm{ml}$ volume trace-metal-free tubes (Teklab Ltd, Durham). A further sample of whole blood was taken to provide a stock suspension of red blood cells and aliquots of this were also stored at $-20^{\circ} \mathrm{C}$.

\section{Analysis of zinc}

The stock zinc standard solution was diluted with deionised water to give working standards containing $0,50,100$ and $150 \mu \mathrm{mol} / \mathrm{l}$ of zinc. A calibration graph was prepared using $40 \mu \mathrm{l}$ of working standard $+40 \mu \mathrm{l}$ of the stock blood sample $+1 \mathrm{ml}$ of butanol to give a $1+26$ dilution. Samples of whole blood $(40 \mu \mathrm{l})$ were added to $40 \mu \mathrm{l}$ of water and $1 \mathrm{ml}$ of butanol. Samples and standards were then directly aspirated into the flame. No physical interferences from viscosity or surface tension of the blood matrix were observed at this dilution. The zinc concentrations of red blood cell suspensions were similarly determined, except that the stock red blood cell suspension was used for preparing the calibration graph. This method gave a within batch RSD and a between batch RSD of $1.3 \%$ and $2.1 \%$ respectively at a concentration of $114 \mu \mathrm{mol} / \mathrm{l}$ of zinc.

\section{Analysis of copper}

The stock copper standard solution was diluted to give working standards of $0,5,10,20,30$ and 40 $\mu \mathrm{mol} / \mathrm{l}$ of copper. A calibration graph was prepared by diluting $100 \mu$ l volumes of the stock blood sample $1+1+1$ with Triton $X-100$ solution and each of the series of working standard solutions. Duplicate samples of whole blood $(100 \mu \mathrm{l})$ were prepared for analysis by diluting with $100 \mu \mathrm{l}$ water and $100 \mu \mathrm{l}$ Triton X-100 solution. Diluted standards and samples were introduced into the flame by means of a PTFE "small volume sampling cup". . This involved substituting a small plastic cup for the standard capillary tubing normally used and injecting $100 \mu \mathrm{l}$ volumes of the diluted samples into the cup using an Oxford automatic pipette (Boehringer Corporation 
Ltd) fitted with plastic sampling tips. This method gave an RSD of $2.6 \%$ and $4.1 \%$ for within batch and between batch precision respectively at a level of $12.6 \mu \mathrm{mol} / 1$ of copper. The copper content of the red blood cell suspensions was also determined as described for whole blood using the stock red blood cell suspension for preparing the calibration graph. Within and between batch precision obtained for these measurements were $3.5 \%$ and $5.2 \%$ respectively at a level of $5.1 \mu \mathrm{mol} / 1$ of copper.

\section{Validation of results}

An internal check on the accuracy of the individual measurements of whole blood and the three blood components analysed was carried out for each blood sample. The values obtained from the white cell, red cell, and plasma measurements were used to obtain a theoretical value for the whole blood. These calculated concentrations were then compared with the directly measured whole blood concentrations and percentage deviations calculated, assuming that the direct determination on whole blood represented $100 \%$ recovery of zinc and copper.

\section{Data processing and statistics}

Data processing was carried out on an ICL 2970 computer and the appropriate statistics were obtained by using the SPSS package. ${ }^{10}$

\section{Results}

The zinc and copper concentrations in leucocytes, erythrocytes, plasma and whole blood are summarised in Table 1 . Table 2 shows the mean concentra-o tions of copper and zinc measured in plasma, red흠 cells and white cells expressed as the amount present $\frac{\text { के }}{\frac{7}{\sigma}}$ per litre of blood, and a comparison of the mean ${ }_{\propto}^{\Phi}$ predicted whole blood concentration from the sumg of these individual fractions and the concentration obtained by direct analysis of whole blood is also? given. Ninety-three per cent of the predicted whole $\overrightarrow{\vec{\omega}}$ blood zinc concentrations fell within $\pm 3 \%$ of theo measured values; the greatest difference was a pre $=\overline{8}$ dicted concentration $6 \%$ greater than the measurediw concentration. Similarly, $95 \%$ of the predicted $\%$ whole blood copper concentrations fell within $\pm 5 \% \cdot$ of the measured values with the largest difference $\frac{-}{\sigma}$ showing a predicted concentration $11 \%$ higher than the measured concentration.

\section{Reference ranges}

The reference ranges for copper and zinc in whole $\mathbb{\Phi}$ blood, red cells, white cells and plasma are shown in $\overrightarrow{ }$ Table 3. These data were derived from the cumulg $-\infty$ tive frequency distribution curves.

Table 1 Zinc and copper concentrations (mean $\pm S D$ ) in leucocytes and erythrocytes (per $10^{6}$ cells), plasma and blood $(\mu \mathrm{mol} / \mathrm{l})$

\begin{tabular}{|c|c|c|c|c|c|}
\hline & & $\begin{array}{l}\text { Leucocyte contents } \\
\text { (pmol/10 cells) }\end{array}$ & $\begin{array}{l}\text { Erythrocyte contents } \\
(\text { pmol/10 cells) }\end{array}$ & Plasma ( $\mu \mathrm{mol} / \mathrm{l})$ & Whole blood ( $\mu \mathrm{mol} / \mathrm{l})$ \\
\hline \multirow[t]{2}{*}{$\begin{array}{l}\text { Total population } \\
\mathrm{n}=119\end{array}$} & & $\begin{array}{r}116 \\
\pm \quad 31\end{array}$ & $\begin{array}{r}16.6 \\
\pm \quad 2.6\end{array}$ & $\begin{array}{r}12.8 \\
\pm \quad 1.9\end{array}$ & $\begin{array}{r}89.0 \\
\pm 10.3\end{array}$ \\
\hline & Copper & $\begin{array}{r}10.9 \\
+\quad 3.7\end{array}$ & $\begin{array}{r}1.12 \\
+\quad 0.17\end{array}$ & $\begin{array}{r}17.6 \\
+4 .\end{array}$ & $\begin{array}{r}15.2 \\
+\quad 2.7\end{array}$ \\
\hline \multirow[t]{2}{*}{$\begin{array}{l}\text { Men } \\
n=55\end{array}$} & & $\begin{array}{r}122 \\
+\quad 34\end{array}$ & $\begin{array}{r}16.3 \\
+\quad 2.4\end{array}$ & $\begin{array}{r} \pm 4.2 \\
13.3\end{array}$ & $\begin{array}{r} \pm 2.7 \\
92.8\end{array}$ \\
\hline & Copper & $\begin{array}{r}11.3 \\
+\quad 3.7\end{array}$ & $\begin{array}{r} \pm 2.4 \\
1.12 \\
+\quad 0.17\end{array}$ & $\begin{array}{r}2.2 \\
15.5\end{array}$ & $\begin{array}{r} \pm 10.3 \\
13.7\end{array}$ \\
\hline \multirow{2}{*}{$\begin{array}{l}\text { Women } \\
n=64\end{array}$} & Zinc & 111 & $\begin{array}{c}0.17 \\
16.8\end{array}$ & $\begin{array}{r} \pm 1.9 \\
12.4\end{array}$ & $\begin{array}{r} \pm 1.4 \\
85.7\end{array}$ \\
\hline & Copper & $\begin{array}{r} \pm 27 \\
10.8 \\
\pm \quad 3.9\end{array}$ & $\begin{array}{l} \pm 2.7 \\
1.13 \\
\pm 0.18\end{array}$ & $\begin{array}{r} \pm 1.5 \\
19.5 \\
\pm \quad 4.7\end{array}$ & $\begin{array}{r} \pm 9.2 \\
16.4 \\
+\quad 3.0\end{array}$ \\
\hline
\end{tabular}

Table 2 Mean zinc and copper concentrations per litre of blood in plasma, red cells and white cells measured separately and of whole blood, predicted and directly measured

\begin{tabular}{|c|c|c|c|c|c|}
\hline & Plasma & Red cells & White cells & $\begin{array}{l}\text { Predicted whole } \\
\text { blood }\end{array}$ & Measured whole blood \\
\hline $\begin{array}{l}\text { Zinc } \\
\text { Copper }\end{array}$ & $\begin{array}{r}7 \cdot 68 \\
10 \cdot 13\end{array}$ & $\begin{array}{r}80.45 \\
5.96\end{array}$ & $\begin{array}{l}0.69 \\
0.04\end{array}$ & $\begin{array}{l}88 \cdot 82 \\
16 \cdot 13\end{array}$ & $\begin{array}{l}88 \cdot 97 \\
15 \cdot 17\end{array}$ \\
\hline \multicolumn{6}{|c|}{$\begin{array}{l}\text { Units of measurement }=\mu \mathrm{mol} / / \text { of whole blood. } \\
\text { No. of subjects }=119 .\end{array}$} \\
\hline
\end{tabular}


EFFECTS OF AGE, SEX, AND PILL

The following groups were selected for statistical analysis: male population; female population; women on the pill; women not on the pill. Mean values for red cells, white cells, plasma and whole blood were compared for both zinc and copper.

Table 4 shows the values obtained for women off and on the pill. Women on the pill were found to have significantly higher concentrations of copper in plasma and whole blood than women not on the pill $(p<0.001)$. However no significant differences in concentrations of zinc were observed for any of the fractions or for whole blood. Since the maximum age of the group of women taking oral contraceptives was $40 \mathrm{yr}$, the group of women not taking oral contraceptives was further subdivided to provide a group with a comparable age range. Again, no significant differences in zinc concentrations were observed between the two groups whereas the concentrations of copper in plasma and whole blood showed the same significant increase in women on the pill.

A comparison of the elemental concentrations in the various samples for men and women revealed significantly higher concentrations of copper in plasma and whole blood for women $(p<0.001)$. However these differences were entirely due to the higher concentrations observed for women taking oral contraceptives, as a comparison of men with women not on the pill showed no significant differ- ence for any of the fractions or whole blood. A significant sex-related difference showing men with higher values was noted only for zinc in whole blood $(\mathrm{p}<0.001)$ and this applied to the total female population and not just those women not on the pill.

\section{Association between variables}

No significant correlations were found between the leucocyte values and the plasma, whole blood or red cell values. No correlation was shown between age and any of the other variables.

\section{Discussion}

The small differences between the calculated and directly measured values for zinc and copper concentrations in whole blood demonstrate good internal control of the separation and analytical techniques employed. Our data for zinc demonstrates that approximately $90 \%$ of the blood zinc is associated with the red cells, with plasma contributing about $9 \%$, and that less than $1 \%$ of the total blood zinc is associated with the white cells. Despite the low contribution to the total blood zinc concentration, the white cells contain about seven times as much zinc per cell as the red cells. This figure is at variance with previous conflicting reports of the ratio of fifteen times ${ }^{12}$ and nine times. ${ }^{13}$ Presumably these discrepancies may be attributed to differences in methodology for the various analyses performed.

Table 3 Reference ranges for copper and zinc in plasma, whole blood, red cells and white cells

\begin{tabular}{|c|c|c|c|c|c|}
\hline & & Plasma ( & $\begin{array}{l}\text { Red cells } \\
\text { (pmol/10 cells) }\end{array}$ & $\begin{array}{l}\text { White cells } \\
\text { (pmol/10 cells) }\end{array}$ & Whole blood ( $\mu$ molll) \\
\hline & Total population & $9-16$ & $\begin{array}{l}11 \cdot 5-20 \\
0.85-1.4\end{array}$ & $\begin{array}{l}77-163 \\
4.0-20.5\end{array}$ & $68-102$ \\
\hline \multirow[t]{2}{*}{ Copper } & Men + Women & $12 \cdot 5-21 \cdot 0$ & & & $11 \cdot 0-16 \cdot 5$ \\
\hline & Women on pill & $15 \cdot 5-29 \cdot 5$ & & & $14-23 \cdot 5$ \\
\hline
\end{tabular}

Table 4 Comparison of copper and zinc concentrations (mean $\pm S D$ ) in blood cells, plasma and whole blood in women on and off pill

\begin{tabular}{|c|c|c|c|c|c|}
\hline & & $\begin{array}{l}\text { Leucocyte contents } \\
\text { (pmol/10 cells) }\end{array}$ & $\begin{array}{l}\text { Erythrocyte contents } \\
\left(\text { pmol } / 10^{\circ} \text { cells) }\right.\end{array}$ & Plasma ( $\mu \mathrm{mol} / \mathrm{l})$ & Whole blood ( $\mu \mathrm{mol} / \mathrm{l})$ \\
\hline $\begin{array}{l}\text { Not on pill } \\
\text { All women } \\
\mathrm{n}=42 \\
\text { Not on pill } \\
\text { Women }<40 \mathrm{yr} \\
\mathrm{n}=30 \\
\text { On pill } \\
(18-38 \mathrm{yr}) \\
\mathrm{n}=22\end{array}$ & $\begin{array}{l}\text { Zinc } \\
\text { Copper } \\
\text { Zinc } \\
\text { Copper } \\
\text { Zinc } \\
\text { Copper }\end{array}$ & $\begin{array}{c}107 \\
\pm 29 \\
10.7 \\
\pm \quad 4.1 \\
104 \\
\pm \quad 22 \\
10.8 \\
\pm \quad 4.5 \\
119 \\
\pm 23 \\
10.8 \\
\pm \quad 3.5\end{array}$ & $\begin{array}{c}17.3 \\
\pm 2.8 \\
1.11 \\
\pm 0.16 \\
17.9 \\
\pm 2.7 \\
1.16 \\
\pm 0.15 \\
15.9 \\
\pm 2.3 \\
\pm 1.17 \\
\pm 0.21\end{array}$ & $\begin{array}{r}12.2 \\
\pm \quad 1.6 \\
17.0 \\
\pm \quad 2.8 \\
12.3 \\
\pm 1.8 \\
16.7 \\
\pm \quad 2.8 \\
12.5 \\
\pm 1.5 \\
24.3 \\
\pm \quad 3.7\end{array}$ & $\begin{array}{r}87.7 \\
\pm \quad 8.5 \\
14.8 \\
\pm \quad 1.6 \\
88.2 \\
\pm \quad 7.8 \\
14.6 \\
\pm 1.7 \\
83.1 \\
\pm 10.2 \\
19.4 \\
\pm \quad 2.6\end{array}$ \\
\hline
\end{tabular}


The suitability of the leucocyte separation technique employed in this study and subsequent analysis of zinc in the white cells has been previously discussed.' Furthermore the excellent agreement between the calculated and directly measured whole blood values indicate that the results obtained from this study are reliable and validate the conclusions drawn from them.

The data obtained for copper demonstrate that a large proportion (approximately 70\%) of the copper in whole blood is present in the plasma with only $0.25 \%$ associated with the white cells and the remainder present in the red cells. Leucocytes were shown to contain about ten times as much copper per cell as the erythrocytes, but there are no other reports with which we can compare our data. As a non-Gaussian distribution was found for some of the parameters measured, reference ranges were obtained from the cumulative frequency distribution curves.

Significant increases in plasma copper concentrations were observed for women taking oral contraceptives and these findings are consistent with previous reports. ${ }^{14-19}$ This study also shows raised concentrations of copper in whole blood in women taking oral contraceptives; these observations are consistent with the positive correlation between plasma and whole blood copper. The increased copper concentration in serum and whole blood are most probably the result of an increased synthesis of caeruloplasmin in response to oestrogen. Increased concentrations of caeruloplasmin with oral contraceptive usage have been previously demonstrated. ${ }^{20}$ Studies have shown however that oral contraceptives do not alter the metabolic balance of copper $^{19}$ and it is interesting to note that no significant increase was found in the copper content of leucocytes or erythrocytes in the group of women taking oral contraceptives.

The present study did not show any significant effect of oral contraceptives on serum zinc values which does not agree with some earlier reports ${ }^{1415}$ but which is in general agreement with more recent publications. ${ }^{16-19}$ It is possible that the decrease in oestrogen content of the newer contraceptive pills may be partly responsible for these conflicting observations. Our results for zinc in whole blood, leucocytes and erythrocytes also show no significant difference between the two groups.

Our findings of no statistically significant differences in plasma, red cell or white cell zinc values between the sexes are in agreement with previous reports. ${ }^{112122}$ The significantly raised concentrations of whole blood zinc found in men $(p<0.001)$ may presumably be attributed to the significantly higher red cell counts found in the male population. This evidence has been well documented. The lack of any significant sex-related difference for copper in whole blood, red cells and plasma has also been previously reported. ${ }^{22}$ No difference was observed between leucocyte copper values for men or women.

The reference ranges for copper and zinc that have been established should provide a suitable basis for clinical studies on patients who have possible body deficiencies of copper and zinc. It is now possible to assess whether the concentration of these trace metals in the leucocytes may provide a more accurate index of body status than other methods currently in use.

We thank Dr HT Delves for his valuable advice and Miss L Snow for typing the manuscript. We are grateful to the Peel Medical Research Trust for financial assistance.

\section{References}

${ }^{1}$ Delves HT. Some clinical aspects of trace elements. Ann Clin Biochem 1982;19:302-6.

.2 Solomons NW. On the assessment of zinc and copper nutriture in man. Am J Clin Nutr 1979;32:856-71.

${ }^{3}$ Foote JW, Delves HT. The distribution of zinc amongst human serum proteins determined by affinity chromatography and $\vec{\theta}$ atomic-absorption spectrophotometry. Analyst 1983 (f press).

4 Bentley SA, Glass HI, Lewis SM, Szur L. Elution correction 通 ${ }^{51} \mathrm{Cr}$ red cell survival studies. Br J Haematol 1974;26:179-842

${ }^{5}$ Prasad AS, Rabbani P, Abbasu A, Bowersox E, Spivey Fox MR. Experimental zinc deficiency in humans. Ann Intern Med 1978;89:483-90.

${ }^{6}$ Keeling PWN, Jones RB, Hilton PJ, Thompson RPH. Reduced leucocyte zinc in liver disease. Gut 1980;21:561-4.

${ }^{7}$ Hinks LJ, Colmsee M, Delves HT. Determination of zinc and copper in isolated leucocytes. Analyst 1982;107:815-23.

${ }^{8}$ Meret S, Henkin RI. Simultaneous determination of copper and zinc in serum, urine and cerebrospinal fluid. Clin Chem 1971;17:369-76.

${ }^{9}$ Manning DC. Aspirating small volume samples in flame atomic absorption spectroscopy. Atomic Absorption Newsletter 1975;14:99-104.

${ }^{10}$ Nie NH, Hull CH, Jenkins JG, Steinbrenner K, Bent DM. Statistical package for the social sciences. 2nd ed. New York: McGraw-Hill, 1975.

$"$ Vallee BL, Gibson JG. The zinc content of normal human whole blood, plasma, leucocytes and erythrocytes. J Biol Chem 1948;176:445-57.

12 Dennes E, Tupper $\mathbf{R}$, Wormall A. The zinc content of erythrocytes and leucocytes of blood from normal and leukaemic subjects. Biochem J 1961;78:578-87.

${ }^{13}$ Fredericks RE, Tanaka KR, Valentine WN A method for measuring zinc in leucocytes and erythrocytes. Anal Biochem $1961 ; 2: 169-73$.

14 Halstead JA, Hackley BM, Smith JC. Plasma zinc and copper in pregnancy and after oral contraceptives. Lancet 1968;ii;278-

is Schenker JG, Hellerstein S, Jungreis E. Serum copper and zinc levels in patients taking oral contraceptives. Fertil Steril $\mathscr{\mathscr { C }}$ $1971 ; 22: 229-34$.

${ }^{16} \mathrm{Vir}$ SC, Love AHG. Zinc and copper nutriture of women taking oral contraceptive agents. Am J Clin Nutr 1981;34:1479-83. 
${ }^{17}$ Vir SC, Love AHG. Effect of oral contraceptive usage on zinc and copper in serum and hair. Int J Vitam Nutr Res 1979;49:330-5.

is Sing EJ, Baccarini IM, O'Neill HJ, Olwin JH. Effects of oral contraceptives on zinc and copper levels in human plasma and endometrium during the menstrual cycle. Arch Gynecol 1978;226:303-6.

19 Crews MG, Taper LJ, Ritchey SJ. Effects of oral contraceptive agents on copper and zinc balance in young women. Am J Clin Nutr 1980;33:1940-5.

${ }^{20}$ Carruthers ME, Hobbs CB, Warren RL. Raised serum coppei and ceruloplasmin levels in subjects taking oral contraceptives. J Clin Pathol 1966;19:498-500.
${ }^{21}$ Nishi Y. Zinc levels in plasma, erythrocyte and leucocyte in healthy children and adults. Hiroshima J Med Sci 1980;29: 7-13.

${ }^{22}$ Herring WB, Leavell BS, Paixao LM, Yoe JH. Trace metals in human plasma and red blood cells. Am J Clin Nutr 1960;8:846-54.

Requests for reprints to: Professor Barbara E Clayton, Department of Chemical Pathology and Human Metabolism, South Laboratory and Pathology Block, Level D, Southampton General Hospital, Tremona Road, Southampton SO9 4XY, England. 